\title{
The Influence of Training on Employee's Performance, Organizational Commitment, and Quality of Medical Services at Jordanian Private Hospitals
}

\author{
Salah M. Diab ${ }^{1} \&$ Musa T. Ajlouni ${ }^{2}$ \\ ${ }^{1}$ Business Administration Department, Economics and Admin. Faculty, Applied Science University, Amman, \\ Jordan \\ ${ }^{2}$ Hospital Admin. Department, Philadelphia University, Amman, Jordan \\ Correspondence: Salah M. Diab, Business Administration Department, Economics and Admin. Faculty, Applied \\ Science University, Shafa-Badran, P. O. BOX 166, 11931, Amman, Jordan. Tel: 962-497-939-0777. E-mail: \\ salahdiab2002@yahoo.com
}

Received: October 23, 2014

Accepted: December 17, 2014

Online Published: January 20, 2015

doi:10.5539/ijbm.v10n2p117

URL: http://dx.doi.org/10.5539/ijbm.v10n2p117

\begin{abstract}
The purpose of this study is to test The Influence of Training on The Employee's Performance and The Quality of Medical Services on Jordanian Private Hospitals). The data of this study were collected through a (380) questionnaire distributed for all types of job in the Jordanian private hospitals). Grynbach constancy coefficients reached $79 \%$, Percentages, means, standard deviation, ANOVA, and, multiple regressions analysis were used to test the study hypotheses, the results indicate that there's a strong relationship between the training component in general and the independent variables (application the stages of training process, training programs diversity, and used modern technology in training programs), there is a variation influence of the training component (combined) on the Performance of workers, quality of medical services, and organizational commitment. And the most influential on is the quality of medical services, the lowest influential one is the organizational commitments, and there's no influence of the used modern technology in training programs as one of the training component on the organizational commitments. On the light of the study results the following recommendations may be submitted create an appropriate regulatory climate, annual training plan, for the process of training and providing appropriate incentives for the trainees, increased the budget allocated for training, in the Jordanian private hospitals, give workers opportunity to choose the training programs, and rationalized administrative decisions regarding the training programs.
\end{abstract}

Keywords: Jordanian private hospitals, training, employee's performance, quality of medical services, organizational commitments

\section{Introduction}

The most important components in the input of the administrative process in any service or productivity organizations are human resources, which are linked with many concepts such as; performance, productivity, satisfaction, training, and many other concepts considered as a part of human resources strategy in most organizations. The attention on training differs from organization to other depending on the commitment of high management, other capabilities, technological uses, the ability and willingness of the organizations to benefit from training to raise the performance, experience, skills, and knowledge of employees. Training also is important for development, creations constantly, and innovations, it make the organization better able to cope with internal and external changes, especially the competition between the private hospitals, which included the Jordanian private hospitals. This case promotes those hospitals to increase their interest in training.

If we takes into account the privacy of the health sector through offering the intangible services, this is posing a direct and quick threat to the hospitals in case of lacking patient satisfaction, which may require that senior management of these hospitals prepare a specialized training programs in order to raise the capabilities and skills of workers, Therefore this study was performed to highlight the need for training and to shed light on the impact of the training components (the application of training process, diversity training programs, use of modern technology in training) on the performance of workers, quality of medical services, and the organizational 
commitment.

\section{Literature Review}

\subsection{Training Concept and Its Importance}

Training is an essential activity for the management of human resources in any organization, training can be defined as the process through which change of behaviors, knowledge and motivation of employees can be achieved in order to improve the compatibility between the characteristics and capabilities of the employee and the job requirements. (Dora \& Sabag, 2008).

As (Mograbi, 2008) mentioned that Casisyo, defined training as the activity of running pilot programs and design it in order to develop individual's collective performance and raise the level of efficiency of the organizational performance (Mograbi, 2008).

(Khalifa, 2000, p. 43) Sees that training and development are vital elements to successful work and growth of hospitals. The training in the hospital is an essential and vital function. Its becomes a strategy and high priority for the high management, in order to create a spirit of creativity, innovation, morale, and affiliation among hospital employees. In addition it makes hospital familiar with the scientific and technological developments and changes. The training is important as it brings a lot of excellence factors and skills that can be owned by employees in any organization, such as: the ability to analyze situations and build initiatives to solve problems, and play a positive role within the working groups.

The foundations and principles of training can be summarized as; training is an essential part of the administrative development and it's a meager tool of modern management, it's considered as a basic function integrated with the functions and activities of human resource management. Training is a planned comprehensive, and continues process that consists of a series of stages and steps, that include designing, implementation, evaluation, and follow-up of the training program.

the basic principles of training, is the need to be meaningful for workers, based on scientific theories, and to taking into account the principle of efficiency, effectiveness, individual differences, and continuously regeneration.

\subsection{Prepare Training Plans}

A training plan is a detailed document that guides the planning and delivery of the training programs .Steps to prepare a training plan; include; Assessment of training needs, set organizational training objectives, create training action plan, implement training initiatives, and revise training.

\subsection{Training Objectives}

1) Management objectives such as: ease the burden on supervisors, skills acquisitions for leaders suitable for their work, assist management to discover the right man in the right place, supply workers with all information they need related to the project objectives and policies, preparing leaders and develop their abilities. (Maher, 1999).

2) Economic and social objectives such as: increased production efficiency, increased the standard of living for workers, increased the efficiency of individuals to achieve the objectives of the organization, change the individual's behavior to suit the requirements of the work performed, and change directions to provide knowledge and skill. (Alqadi, 1998).

3) Technical objectives such as; reduced the maintenance costs, improve customer services, increased work efficiency, reduce the damaged and lost, raise the technical level of workers, and improve worker performance.

\subsection{The Areas of Training}

There are five key areas for training: Knowledge, skill, techniques, attitudes, experience. These areas can be achieved through a good training programs goal related to these areas. The training can be divided according to different bases, including location, time, type.... etc.

\subsection{Performance}

The performance can be considered as the output capability one hour work or the amount of output per worker during a specific time (Aldmrani, 1987). The performance also is the ratio between the quantity produced and the labor used in production of a certain amount (Suleiman, 1998), the performance has a certain character; quantity, quality, and comprehensive. In addition to that, any individual performance reflects his ability and knowledge to achieve the goals associated with the accuracy, whatever the nature of the work (Shanawany, 2001). All services 
and productive organizations interested in performance because it measures the efficiency and effectiveness of the organization as well as individuals and groups.

\subsection{Quality of Medical Services}

Quality of medical services as (David, 1999) defined is perceived from three views, the patients, medical groups, and hospital administrators. The patient looks to quality of medical care as to what extent that services provided by the hospital are meeting his required needs, medical groups look to it as the skills and experience of the individuals in the hospital; and the hospital administrators look to it as achieving efficiency and effectiveness in the provision of medical service. The quality of medical services reduces the errors, reduce patient waiting time, provide all kinds of medical services with acceptable level, in addition to ethics commitment of the medical profession (Diab, 2010).

The perceived quality of medical service through a private entrance so-called the gap which it is the difference between the services provided and the expected service to be submitted or the difference between service provided and the standards set for the medical services. There are five dimensions for the quality of medical services, which are; access to services, technical competence, efficiency and effectiveness, interpersonal relationships, health safety, and amenities. (Al-mansur, \& Yaser, 1997).

\subsection{Organizational Commitment}

The organizational commitment defined as the psychological readiness and internal desire for working in the organization, it is also the readiness to make the utmost possible effort for the benefit of the organization and cravings stay in the organization through extra extensive effort for the sake of the success of the organization and achieving its goals (harrries, 2003, p. 31). Also organizational commitment is considered as a strong link between the employees and the organization when employee's values and goals are compatible with the organization goals and values. Organizational commitment has a set of dimensions: the organizational loyalty, responsibility to the organization, the desire to continue in the work, and the faith with the organization. (Obeidi, 2012, p. 83).

\section{Previous Studies}

There are many studies related to the topic of the study, but not related to hospitals, examples of these studies are:

Study by (Mia, Ali, and others, 2009), measuring the impact of training on the performance of workers: An Empirical Study of the Directorate of Education in Al Buraimi Governorate in the Sultanate of Oman. Results of the study, showed an impact of training on the performance of teachers, and it increased their productivity. The researchers recommended giving more attention to the quality of the training programs offered to teachers.

Study of (Jalal \& Abu Bakr, 2010) the effect of training technical programs on efficiency of workers in the Palestinian financial market. The study found that the technical training leads to stability in the work, and increases the efficiency of workers in the Palestinian financial market.

Study of (Tarawneh, 2009) the obligation to apply the stages of training and its impact in the field of performance of employees, the study found that the existence of an obligation to apply the stages of training with an effect of this commitment on the performance of employees, the researcher provided some recommendations as, the need to take into account the diversity of training programs and encouraging employees to comply with all phases of training.

Study of (Ghannam, and others, 2010) the impact of training on the performance of the employees in the Palestinian insurance sector, the study found that their a relationship between the training and performance improvement, and the external training is the best training procedure, the study also found that there are effect of the training on the organizational commitment of employees in the insurance sector in Palestine.

Study of (Al-Obeidi, \& Jawaher, 2013) the effect of following a creative approach trend and strategy training on the employees performance in the Kuwait Oil Company, the study found a strong relationship between strategy training and the employees performance, the researcher emphasized the need to focus on strategic training activities in Kuwait Oil, taking into account the internal and external factors of the company.

Study of (Ntal, 2007) the role of training in development of the competencies of school managers in the United Nation Relief World Agencies (UNRWA) in Gaza Strip. The study found that training increases the efficiency and performance of school managers.

Study of (Teresa, \& Brannik, 2002) service management practice- performance model: A focus on Training Practice. The studies found the presence of close relationship between training and service performance and 
demonstrated that extensive training activities enhance this relationship.

Study of (Danials, 2003) employee training: a strategic approach to better returned on investment a study on British banks, the study found that training contributes significantly to the development of the skills and learning of employees and achieve a high level of quality, and create an organizational culture supportive of the goals of the organization.

Study of (Sezar, 2009) an analysis on relations between implementation of training activities and human resources management organizations in service businesses: A sample in hotels. The study concluded that in the hotels, where they have a manager of human resources and training, the workers have outstanding performance; in addition to that there is a close relationship between training programs offered and management of human resources.

Study of (Lateef \& Louay, 2008) The role of training in the evaluation of the efficiency of the employees performance, within the hotel sector-a study of the views of managers and heads of departments and employees at the Rashid Hotel-Baghdad, the study found the presence of great importance to training in evaluating the performance of employees and achieving a high level of customer satisfaction.

What distinguishes this study from previous studies that its deal with the hospital sector, which have not been targeted frequently for similar research-according to the researcher knowledge-; in addition this study has linked training components with the dependent variables, performance, and organizational commitment and the quality of medical services in Jordanian private hospitals, also using more than statistical treatment to examine the study hypotheses.

\section{Study Objectives}

This study aims to achieve the following:

- To provide a simple theoretical framework for the study variables.

- To answer the questions of the study problem, as described in the previous part.

- Test and measure the impact of the training components (application of stages of the training process, diversity of training programs, and use of modern technology in training) on the employee's performance, the quality of medical services, and the organizational commitment, at the Jordanian private hospitals.

- Make appropriate recommendations in the light of the results of this study, which may lead to improved performance, better quality of medical services, and organizational commitment

- Addressing a topic that hasn't been studied before, at the Jordanian private hospitals.

\section{The Importance of the Study}

In the light of accelerated scientific and technological developments in the field of medical services and the increasing competition among private hospitals in Jordan to gain bigger share of the growing medical tourism market, training and continuous development of human resources is gaining more priority and emphasis by Jordanian private hospitals. The other aspect that gives importance to the study is that training linked to human resources, which is considered as the main component input in the administrative process. Also the importance of the study comes through what (Mashhadani, 2002), set about raising production efficiency, and improving the regulatory climate through training. As well as (Abbas, 2006), set, the training leads to the rationalization of administrative decisions and build a base of effective communications. In addition to that, the researchers expect that Jordanian private hospitals may take advantage of the results of this research.

\section{The Rational and Problem of the Research}

The problem of the study concentrated on analysis of the training at the Jordanian private hospitals. The researchers had worked at the health sector in Jordan for many years, they want to examine the impact for training component on a variety of selected factors within the private hospitals, so the problem of the study is to identify if there's an impact of training components (application stages of the training process, diversity training programs, use of modern technology in training) on (the performance of employees, the quality of medical services, and organizational commitment) in the Jordanian private hospitals. The problem of this study summarized in a range of questions, which are:

- What is the impact of the training components (application of stages of the training process, diversity of training programs, and use of modern technology in training) on the employee's performance in the Jordanian private hospitals? 
- What is the impact of the training components (application of stages of the training process, diversity of training programs, and use of modern technology in training) on the quality of medical services at the Jordanian private hospitals?

- What is the impact of the training components (application of stages of the training process, diversity of training programs, and use of modern technology in training) on the organizational commitment at the Jordanian private hospitals?

\section{Framework and Study Hypothesis}

\subsection{Study Framework}

The proposed framework for this study is illustrated in Figure 1. The framework shows the impact of the training component (application the stages of training process, training programs diversity, and used modern technology in training programs) on the performance of workers, quality of medical services, and organizational commitment.

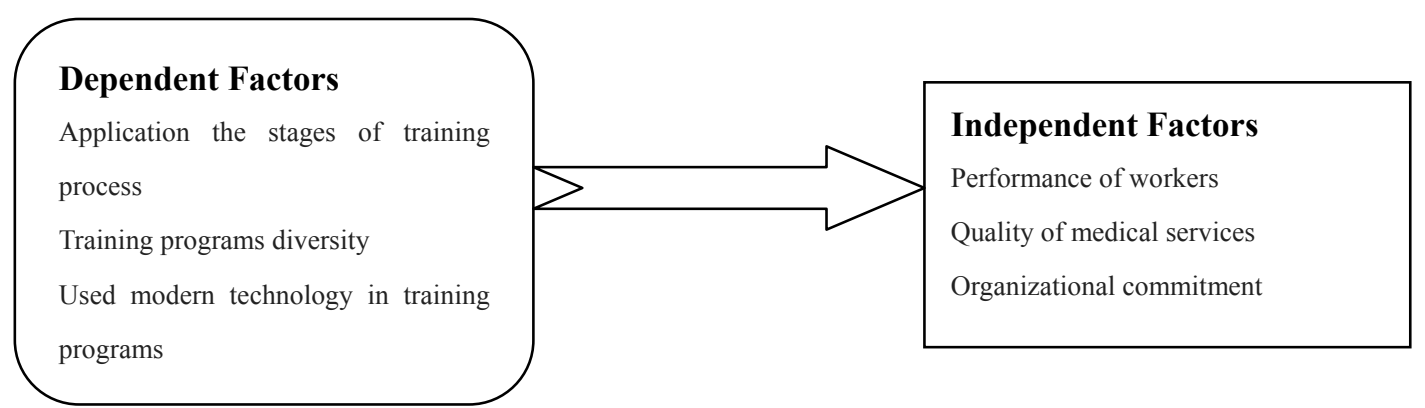

Figure 1. Study framework

Note. The study model was used to study Tarawneh, 2009.

\subsection{Study Hypothesis}

It consisted of three major hypotheses, each one consisted of three minor hypotheses as follows:

\subsubsection{First Major Hypothesis}

H0: There is no statistically significant effect of the training components (the application of training process, diversity training programs, use of modern technology in training) on the employees' performance in Jordanian private hospitals.

H0: There is no statistically significant effect of the application of training process on the employees' performance in Jordanian private hospitals.

H0: There is no statistically significant effect of the diversity training programs on the employees' performance in Jordanian private hospitals.

H0: There is no statistically significant effect of the used of modern technology in training on the employees' performance in Jordanian private hospitals.

\subsubsection{Second Major Hypothesis}

H0: There is no statistically significant effect of the training components (the application of training process, diversity training programs, use of modern technology in training) on the quality of medical services in Jordanian private hospitals.

H0: There is no statistically significant effect of the application of training process, on the quality of medical services in Jordanian private hospitals.

H0: There is no statistically significant effect of the diversity training programs on the quality of medical services in Jordanian private hospitals.

H0: There is no statistically significant effect of the used of modern technology in training on the quality of medical services in Jordanian private hospitals.

7.2.3 Third Major Hypothesis

H0: There is no statistically significant effect of the training components (the application of training process, 
diversity training programs, use of modern technology in training) on the organizational commitment in Jordanian private hospitals.

H0: There is no statistically significant effect of the application of training process on the organizational commitment in Jordanian private hospitals.

H0: There is no statistically significant effect of the diversity training programs on the organizational commitment in Jordanian private hospitals.

H0: There is no statistically significant effect of the used of modern technology in training) on the organizational commitment in Jordanian private hospitals.

\section{Methods and Procedures}

\subsection{Study's Methodology}

Theoretical framework was developed through different sources of books, scientific journals, and the internet. The preliminary data were obtained through designing a questionnaire that consists of forty (40) clauses; those (40) clauses reflect all the dependent and nondependent variables.

\subsection{The Populations and the Sample of the Study}

Study's population consisted of all the employees in Jordanian private hospitals, which are around (75) hospital, (according to non-published report of the ministry of health in Jordan) with (20000) employees in deferent positions and jobs. According to the (Krejcie and Morgan table for determining the sample size) related to the population size, the sample size was (380), the questionnaire distributed randomly to the sample size from all positions and jobs.

\subsection{Data Collection Methods}

The main instrument of this study relays on the questionnaire, it was developed in the form of a questionnaire after reviewing previous studies in this field. It consisted of forty (40) clauses, which were designed according to (Likart scale): (strongly disagree, disagree, don't know, agree, strongly agree,), and given the weights $(1,2,3,4$, and 5). The higher the mean, indicates to higher degree of consent on the clause.

\subsection{Internal Consistency}

(Grynbach Alpha confections) were obtained for internal consistency between the clauses attitudes scale. As (Grynbach coefficients) reached $79.0 \%$, it is considered a high value indicates to the study's instrument constancy.

\subsection{Statistical Methods Used}

The following statistical methods were used for statement attributes of the study sample and for examining the hypotheses of the study: frequencies, percentages, means, standard deviation, multiple linear regression analysis, ANOVA analysis, and Pearson correlation.

\section{Results and Testing Research Hypothesis}

Table 1. General characteristics of the study sample

\begin{tabular}{|c|c|c|}
\hline Job employee character. & Sample No(380) & PERCENTAGE \\
\hline \multicolumn{3}{|l|}{ JOB } \\
\hline Administrative and Finance & 90 & $24 \%$ \\
\hline $\begin{array}{l}\text { Medical staff (doctors, nurses, and } \\
\text { paramedical,...etc) }\end{array}$ & 220 & $58 \%$ \\
\hline Technical staff (engineers, maintenance, ....etc & 70 & $18 \%$ \\
\hline \multicolumn{3}{|l|}{ GENDER } \\
\hline Male & 225 & $59 \%$ \\
\hline Female & 155 & $41 \%$ \\
\hline \multicolumn{3}{|l|}{ AGE } \\
\hline Less than 25 years & 30 & $8 \%$ \\
\hline 26-35 years & 90 & $24 \%$ \\
\hline $36-45$ years & 180 & $48 \%$ \\
\hline $46-55$ years & 63 & $16 \%$ \\
\hline
\end{tabular}




\begin{tabular}{lll}
\hline 56 years -and above & 17 & $4 \%$ \\
\hline SOCIAL STATUS & 286 & $75 \%$ \\
Married & 94 & $25 \%$ \\
Single & & \\
\hline EXPERIENCE & 70 & $18 \%$ \\
$1-5$ Years & 148 & $39 \%$ \\
6-10 Years & 72 & $19 \%$ \\
$11-15$ year & 90 & $24 \%$ \\
16 years and more & & \\
\hline QUALIFICATION & 33 & $9 \%$ \\
Diploma and less & 237 & $62 \%$ \\
BA/Bachelor & 77 & $20 \%$ \\
MA/Master & 33 & $9 \%$ \\
PhD/Medical board & & \\
\hline
\end{tabular}

Table 1 appears that (58\%) percent of the sample are medical staff, which are the higher percentage. $(59 \%)$ of the sample are male, the greater percentage (48\%) form those age between (36-45) years old, It is also noticed that the higher percentage (75\%) married, (39\%) of the study sample has (6-10) years' experience, The higher percentage $(62 \%)$ has Bachelor degree.

Table 2. The mean and standard deviation for the study sample answers about the training component and the other dependent factors

\begin{tabular}{lll}
\hline Dependant and independent factors & MEAN & STD. Deviation \\
\hline Application the stages of training process & 3.98 & 0.406 \\
training programs Diversity & 4.28 & 0.511 \\
Used modern technology in training programs & 4.30 & 0.460 \\
Performance of workers & 4.25 & 0.489 \\
Quality of medical services & 4.33 & 0.440 \\
Organizational commitment & 4.20 & 0.461 \\
Total & 4.22 & 0.448 \\
\hline
\end{tabular}

Table 2 shows the arithmetic means and standard deviation for the sample answer, related to dependent and independent variables, according to the means in table 2 , the sample members understand each variable very well, because of all the means for all the variables are greater than (3), the higher understanding is the quality of medical services with the higher means (4.33).

Table 3. The Pearson correlation of the relationship between dependent and independent variables

\begin{tabular}{|c|c|c|c|}
\hline variables & $\begin{array}{l}\text { Application the stages of training } \\
\text { process }\end{array}$ & $\begin{array}{l}\text { training } \quad \text { programs } \\
\text { Diversity }\end{array}$ & $\begin{array}{l}\text { Used modern technology in training } \\
\text { programs }\end{array}$ \\
\hline Performance of workers & 0.847 & 0.837 & 0.614 \\
\hline $\begin{array}{l}\text { Quality of medical } \\
\text { services }\end{array}$ & 0.677 & 0.654 & 0.531 \\
\hline $\begin{array}{l}\text { Organizational } \\
\text { commitment }\end{array}$ & 0.715 & 0.546 & 0.544 \\
\hline At the level of alpha $=5 \%$ & & & \\
\hline
\end{tabular}

Table 3 show the Pearson correlation of the relationship between the dependent and independent factors, the higher relation between the application of the stages of training process and performance of workers with Pearson correlation (0.847), then the relation between training programs diversity and performance of workers with Pearson correlation (0.837), then the relation between the application of the stages of training process and organizational commitment with Pearson correlation (0.715), but the lowest Pearson correlation is $(0.544)$ using 
modern technology in training programs and organizational commitment. These results confirm that their a different strong relationship between the dependents and independent variables.

Table 4. The multiple linear regression analysis of the influence of the training component (combined) on the performance of workers, quality of medical services, and organizational commitment

\begin{tabular}{llllll}
\hline & B & T & Sig. & R2 & F \\
\hline Performance of workers & 0.32 & 4.43 & 0.000 & 0.393 & 28.80 \\
Quality of medical services & 0.41 & 5.33 & 0.000 & 0.299 & 29.54 \\
Organizational commitment & 0.30 & 4.12 & 0.000 & 0.312 & 27.12 \\
\hline
\end{tabular}

Table 4 shows the result of the multiple linear regressions, there is an influence of the training component (combined) on the performance of workers, quality of medical services, and organizational commitment. Is the most influential on the quality of medical services where (B) (0.41), and (t)value (5.33) with (0.000) significance, the lowest influential where on the organizational commitments, where(B) $(0.30)$, and $(t) v a l u e(4.12)$ with $(0.000)$ significance. The result indicates a variation influential for the training component on the performance of workers, quality of medical services, and organizational commitment.

Table 5. The ANOVA analysis of the influence of the training component (combined) on the performance of workers, quality of medical services, and organizational commitment

\begin{tabular}{|c|c|c|c|c|c|c|}
\hline & & $\mathbf{R} 2$ & Degrees & Rate & $\mathbf{F}$ & Sig. \\
\hline \multirow{3}{*}{$\begin{array}{l}\text { Performance } \\
\text { workers }\end{array}$} & The sum of squares regression & 1.532 & 1.0 & 1.355 & 6.974 & 0.000 \\
\hline & sum of squared residuals & 13.472 & 58 & & & \\
\hline & TOTAL & 15.00 & 59 & & & \\
\hline \multirow{3}{*}{$\begin{array}{l}\text { Quality of medical } \\
\text { services }\end{array}$} & The sum of squares regression & 1.61 & 1.0 & 1.412 & 7.123 & 0.003 \\
\hline & sum of squared residuals & 14.012 & 58 & & & \\
\hline & TOTAL & 15.61 & 59 & & & \\
\hline \multirow{3}{*}{$\begin{array}{l}\text { Organizational } \\
\text { commitment }\end{array}$} & The sum of squares regression & 1.70 & 1.0 & 1.231 & 6.376 & 0.002 \\
\hline & sum of squared residuals & 13.676 & 57 & & & \\
\hline & TOTAL & 15.34 & 58 & & & \\
\hline
\end{tabular}

Table 5 shows the influence of the training component (combined) on the performance of workers, quality of medical services, and organizational commitment. The results in table 5 shows that the training component (combined) influenced on the workers performance, where (F) value (6.974), less than (F) tabled value, and with (0.000) significance. Also theirs an influenced on the quality of medical services, and organizational commitment, where (F) value (7.123), (6.376) which are less than (F) tabledWith (0.002), (0.003) significance, which are less than alpha value (0.05). 
Table 6. Multiple linear regression analysis of the influence of each component of training on each independent factors

\begin{tabular}{|c|c|c|c|c|c|c|c|c|c|}
\hline \multirow[t]{2}{*}{ variables } & \multicolumn{2}{|c|}{$\begin{array}{l}\text { Application the } \\
\text { training process }\end{array}$} & \multirow{2}{*}{$\begin{array}{c}\text { tages of } \\
\text { Sig. } \\
\end{array}$} & \multicolumn{3}{|c|}{ training programs Diversity } & \multicolumn{3}{|c|}{$\begin{array}{l}\text { Used modern technology in } \\
\text { training programs }\end{array}$} \\
\hline & $\mathrm{B}$ & $\mathrm{T}$ & & $\mathrm{B}$ & $\mathrm{T}$ & Sig. & $\mathrm{B}$ & $\mathrm{T}$ & Sig. \\
\hline $\begin{array}{l}\text { Performance of } \\
\text { workers }\end{array}$ & 0.298 & 4.98 & 0.000 & 0.245 & 4.27 & 0.001 & 0.29 & 2.77 & 0.000 \\
\hline $\begin{array}{l}\text { Quality of medical } \\
\text { services }\end{array}$ & 0.318 & 4.22 & 0.000 & 0.271 & 4.44 & 0.000 & 0.31 & 3.15 & 0.000 \\
\hline \multirow[t]{4}{*}{$\begin{array}{l}\text { Organizational } \\
\text { commitment }\end{array}$} & 0.43 & 4.26 & 0.000 & 0.43 & 4.33 & 0.000 & 0.32 & 3.033 & 0.065 \\
\hline & \multicolumn{3}{|c|}{$\mathrm{R} 2=0.29$} & \multicolumn{3}{|c|}{$\mathrm{R} 2=0.34$} & \multicolumn{3}{|c|}{$\mathrm{R} 2=0.31$} \\
\hline & \multicolumn{3}{|c|}{$\mathrm{F}=30.47$} & \multicolumn{3}{|c|}{$F=29.40$} & \multicolumn{3}{|c|}{$F=26.20$} \\
\hline & \multicolumn{3}{|c|}{$\mathrm{Sig}=0.001$} & \multicolumn{3}{|c|}{ Sig. $=0.000$} & \multicolumn{3}{|c|}{ Sig. $=0.000$} \\
\hline
\end{tabular}

Table 6 shows the influence of each component of training on each independent variable. As we see in table 6 that the most influence training component is application the stages of training process on the performance of the worker with (T) value (4.98), then the influence of training programs diversity on the quality medical services with ( $\mathrm{T})$ value (4.44), on the other hand the most less influence of the training component is used modern technology in training programs on performance of the worker with (T) value (2.77), table (6) also shows their no influence of the used modern technology in training programs as one of the training component on the organizational commitments with(0.065) significance, which its greater than alpha value.

\section{Conclusions and Recommendations}

\subsection{Conclusions of This Study Showed the Following}

$\checkmark \quad$ The sample members understand each variable very well.

$\checkmark \quad$ There's a strong relationship between the training component in general and the independent variables (Application the Stages of Training Process, Training Programs Diversity, and Used modern technology in training programs).

$\checkmark \quad$ The higher relation between the application of the stages of training process and performance of workers then the relation between training programs diversity and performance of workers.

$\checkmark$ The lowest relation between using modern technology in training programs and organizational commitment.

$\checkmark \quad$ There is an influence of the training Component (combined) on the Performance of workers, Quality of medical services, and organizational commitment. And the most influential on is the Quality of medical services.

$\checkmark$ The lowest influential one is the organizational commitments.

$\checkmark \quad$ In general theirs a variation influential for the training component (combined) on the performance of workers, quality of medical services, and organizational commitment.

$\checkmark \quad$ The most influence training component is application the stages of training process on the performance of the worker, then the influence of training programs diversity on the quality medical services.

$\checkmark$ The less influence of the training component is used modern technology in training programs on performance of the worker.

$\checkmark \quad$ There's no influence of the used modern technology in training programs as one of the training component on the organizational commitments.

\subsection{Recommendations}

In the light of the study result and the researcher observations, they suggested the following Recommendations:

Create an appropriate regulatory climate for the process of training and providing appropriate incentives for the trainees.

Create an annual training plan according to the workers training needs in the Jordanian private hospitals.

Convince the high management in the hospitals with the importance of training and its role in raising the 
efficiency of workers in the Jordanian private hospitals- .increase the budget allocated for training, education and scientific research in the Jordanian private hospitals

Give workers in the Jordanian private hospitals the opportunity to choose the quality of the training programs they need.

Work to make the training programs are compatible with the goals set for it in the Jordanian private hospitals, and choosing the training programs which are consistent with the appropriate times for the employees to encourage them to attend these training programs. To keep up the training programs with medical scientific and technological developments. Rationalized administrative decisions regarding the training programs.

\section{Acknowledgment}

The Author is Grateful to The Applied Science University, Amman, Jordan for the Full Financial Support Granted to This Research Project (Grant No.BI/98).

\section{References}

Abbas, S. (2006). Human Resource Management strategic entrance (2nd ed.). Dar Wael for Publishing and Distribution, Amman, Jordan.

Aldmrani, A. (1987). Measure the Effectiveness of Organizations. Journal of Management.

Almansour, Y. (1997). Total Quality Management An Empirical Study On Jordanian Health Sector. Un-published PhD, Thesis, Bagdad University, public administration department.

Alqadi, M. (1998). The role of Vocational Training in the Preparation of the Workforce. Madbouly Library Publishing, Amman, Jordan.

Danials, S. (2003). Employee Training: A strategic Approach to better returned on Investment. Journal of Business Strategy, 24(5), 39-42. http://dx.doi.org/10.1108/02756660310698713

David, H. (1999). Achieve Total Quality. London: Director Book England.

Diab, S. (2010). Primary Health Care Management (1st ed.). Dar alfeker for Publications, Amman. Jordan .

Dora, \& Sabahg. (2008). Human Resource Management. Dar Wael for publication, Amman, Jordan.

Gary, D. (2010). Human Resources Management. Pearson Education International, Prentice, Hall.

George, T. M., \& John, B. (1998). Human Resources Management. Richard D.Irwin .Inc. U.S.A.

Ghannam. (2010). The impact of training on the performance of employees in the insurance sector of the Palestinian. Unpublished research, An-Najah University, Nablus, Palestine.

Ibrahim, M. (2009). Human Resource Management. University House, Alexandria, ARE.

Jalal, A. B. (2010). The effect of training technical programs on efficiency of workers in the Palestinian financial market. Unpublished research, An-Najah University, Nablus, Palestine.

Lateef, L. (2008). The role of training in the evaluation of the efficiency of the employees performance, within the hotel sector-a study of the views of managers and heads of departments and employees at the Rashid Hotel-Baghdad. Journal of Business and Economics, 71.

Maher, A. (1999). Human Resource Management. University House for Printing and Publishing, Amman, Jordan.

Mia et al. (2009). Measuring the impact of training on the performance of workers an Empirical Study of the Directorate of Education in Al Buraimi Governorate in the Sultanate of Oman. Economic Sciences, Legal, 31(1).

Mograbi, A. H. (2007). Recent Trends in Studies and Human Resource Management Practices. Modern Library, Amman, Jordan.

Ntal, J. (2007). The role of training in development the competencies of school managers in the United Nation Relief World Agencies (UNRWA) in Gaza Strip. Unpublished MA Thesis, Department of Business Administration, Islamic University-gzh.

Obeidi, J. (2013). The effect of following a creative approach trend and strategy training on the employees performance in the Kuwait Oil Company. Unpublished MA Thesis, University of the Middle East, Amman, Jordan .

Salem, M. (2009). Human Resource Management. Dar enrich for Publishing and Distribution, Amman, Jordan 
Sezar. (2009). An analysis on relations between implementation of training activities and human resources management organizations in service businesses. Journal of European Industrial Training, 28(5), 370-382.

Shanawany, S. (2001). Personnel management and human relations. ARE.

Suleiman, H. (1998). Organizational behavior and performance. Dar Egyptian Universities, Alexandria, Egypt.

Tarawneh, T. (2009). The obligation to apply the stages of training and its impact in the field of performance of employees. Arab Journal of Security Studies and Training, 26(51).

Teresa, B., Sean, B., Brian, E., Evelyn, R., \& Sean, E. (2002). Service management practice- performance model: A focus on Training Practice. Journal of European Industrial Training, 26(8), 394-403. http://dx.doi.org/10.1108/03090590210444973

\section{Copyrights}

Copyright for this article is retained by the author(s), with first publication rights granted to the journal.

This is an open-access article distributed under the terms and conditions of the Creative Commons Attribution license (http://creativecommons.org/licenses/by/3.0/). 